\title{
Manuscripts and Margins \\ The Case of the Late Mediaeval Slavonic Hexaemeron Collection or Šestodnevnik and its Greek Source Text
}

\author{
Lara Sels, KU Leuven
}

\section{Works $^{1}$}

Shortly after the conversion of the Slavs, the $4^{\text {th }}$-century commentaries on the Biblical account of creation written by the two Cappadocian Fathers and brothers Basil of Caesarea and Gregory of Nyssa made their way into Slavonic literature: Basil's homiletic work (Homiliae in Hexaemeron; CPG 2835) served as one of the main sources of an exegetical compilation called Šestodnev (viz. Hexaemeron), a huge collection of translated and paraphrased excerpts ascribed to John the Exarch. ${ }^{2}$ Gregory's anthropological treatise On the Making of Man (De hominis opificio; CPG 3154) was among its numerous minor sources. The Šestodnev was made in $9^{\text {th }}-/$ early $10^{\text {th }}$-century Bulgaria, while another translation, in full this time, of both Basil's Homiliae and Gregory's treatise was produced four centuries later, at a time when monastic book culture prospered in the late medieval Balkan states Bulgaria and Serbia. ${ }^{3}$

The bare fact that the Cappadocians' writings on the creation were translated twice reveals little about their impact on Slav culture. It is interesting, however, to look at the particulars of the two Slavonic versions, esp. at the way in which the translators dealt with their Greek models and prepared the works to be read in their new environment. In the early period, Basil's homilies were excerpted and juxtaposed to fragments from Severian of Gabala's De mundi creatione orationes (CPG 4194), integrated into the Šestodnev without systematic indication of fragment boundaries and authorship. ${ }^{4}$ In some passages the translator allowed himself to proceed freely, adding and omitting phrases at will, often in an attempt to simplify the Greek or to make his version more explicit. Gregory of Nyssa's learned treatise was not really translated but pieces

${ }^{1}$ This paper maintains a terminological distinction between 'work/oeuvre' and 'text/texte', as defined in Patrick Andrist, Paul Canart, and Marilena Maniaci, La Syntaxe Du Codex: Essai de Codicologie Structurale, Bibliologia 34 (Turnhout, 2013), 51: “... le texte est compris comme « une suite écrite de mots dans une séquence significative ».... Nous entendons le texte dans un sens matériel, dans la mesure où il exige une matérialisation des mots qui le composent sur le support d'écriture" and "Par contraste avec le texte, l'œuvre est "une production organisée de l'esprit, considérée dans un sens immatériel »."

${ }^{2}$ Ed. Rudolf Aitzetmüller, Das Hexaemeron des Exarchen Johannes, 7 vols, Editiones monumentorum slavicorum veteris dialecti (Graz, 1958-1975). For its dating between 893 and 917, see Ivan Dujčev, 'L'Hexaémeron de Jean l'Exarque', Byzantinoslavica 39 (1978), 212.

${ }^{3}$ Only the part containing Gregory of Nyssa's treatise has been published, see Lara Sels, Gregory of Nyssa. De hominis opificio, O obrazě člověka, The Fourteenth-Century Slavonic Translation. A Critical Edition with Greek Parallel and Commentary, Bausteine zur Slavischen Philologie und Kulturgeschichte, neue Folge, Reihe B, Editionen 21 (Köln, 2009).

${ }^{4}$ There is a general note on the sources in the preface to the Šestodnev: "We have not composed these six books all by ourselves, but have taken from Saint Basil's Hexaemeron now the true words, then the ideas; in the same way [we have taken something] from John, and, again, something else from others" (Slavonic text in R. Aitzetmüller, Hexaemeron, vol. 1 [1958], 43-4, 6b). 
were integrated in the Šestodnev's sixth book as subtle allusions and comments. ${ }^{5}$ It is safe to say that it was impossible for any reader to derive a coherent picture of Cappadocian thought on the creation from the early Slavonic Šestodnev, which first and foremost aimed at providing general instruction, introducing and securing basic ideas of Christian cosmology. The textual relationships and dependencies within the Šestodnev and its (not always consistent) worldview sadly remain understudied, in spite of its great resonance in the Slavia orthodoxa.

The present article will not focus on the early Šestodnev but on the late $13^{\text {th }}$ - or $14^{\text {th }}$-century translation in full of the two Cappadocian Genesis commentaries. Here we find both works clearly identified and ascribed in their titles to Basil and Gregory, joined together in a single Šestodnevnik, viz. the Homiliae in Hexaemeron followed immediately by the De hominis opificio and concluded by the formula "end of the Hexaemeron". 6 This constellation has been shown to reflect a Greek translation model, as a 'regular Hexaemeron corpus' with similar features ("le corpus normal de l'Hexaéméron / das normale Hexaemeron-Corpus") ) is also found in the Greek tradition (see infra).

In the case of this late mediaeval Šestodnevnik, it is the translation's hyper-literalism that raises questions about its understandability and hence about the quality of the Slavonic reception of Cappadocian thought. The translation's apparently limited distribution may, perhaps, be seen in that light. Rooted within the broader context of late mediaeval monasticism, the translation exemplifies an often-noted (but not generalizable) shift towards a more formal approach to translation and an increased influence of Greek on Church Slavonic spelling, morphology, syntax and word order - in some cases to the point of incomprehensibility. The causes for this seemingly mechanical approach to translation are still not fully clear. A perception of the Greek sources as standards of truth and a general concern for the work's integrity and the translation's correctness are certainly part of the explanation, as is the fact that the language of the later period was better fit to accommodate such literal renderings (because of its previous development under the influence of Greek). It is also possible that, at the time, certain monastic attitudes contributed to these literalist tendencies: on the one hand, an approach to representation informed by the Byzantine theology of image ( $\dot{i} \kappa \tilde{\omega} v),{ }^{8}$ and, on the other, a

\footnotetext{
${ }^{5}$ See Lara Sels, 'John the Exarch and His Sources: New Sources of the Sixth Book of the Šestodnev', Slavica Gandensia 35 (2008), 123-49.

6 Коньць шестодневьникоу - see L. Sels, De hominis opificio (2009), 20. The joint transmission of the two works, both in Greek and Slavonic, is in line with Basil's own referring to a future treatment of the creation of man in his last homily (see Emmanuel Amand de Mendieta and Stig Y. Rudberg [eds.], Homilien zum Hexaemeron: Basilius von Caesarea, Griechischen christlichen Schriftsteller der ersten drei Jahrhunderte, neue Folge, Bd. 2 [Berlin, 1997], 160, 11.14-15), and with Gregory's explicitly presenting his work as an addition to Basil's teaching (see George H. Forbes [ed.], 'De Conditione Hominis', in his Sancti Patris Nostri Gregorii Nysseni Basilii Magni Fratris quae supersunt omnia, vol. 1 [Burntisland, 1855], 104, §2).

${ }^{7}$ Emmanuel Amand de Mendieta and Stig Y. Rudberg, Basile de Césarée. La tradition manuscrite directe des neuf homélies sur l'Hexaéméron, Texte und Untersuchungen zur Geschichte der altchristlichen Literatur 123 (Berlin, 1980), 3, and E. Amand de Mendieta and S. Rudberg, Homilien zum Hexaemeron (1997), ix.

${ }^{8}$ See, for instance, the arguments on likeness and participation (viz. on archetypal presence in an image through resemblance) in John of Damascus' treatises against the iconoclasts (where parallels are often drawn between images and writing), ed. Bonifatius Kotter, Die Schriften des Johannes von Damaskos, III, Contra imaginum calumniatores orationes tres, Patristische Texte und Studien 17 (Berlin - New York, 1975).
} 
distrust of discursive reason inspired by monastic virtues as hèsychia and nèpsis. ${ }^{9}$ Sources indicate that, as producers of writing, monks perceived themselves as humble vessels of grace rather than as creative writers, ${ }^{10}$ an attitude that would privilege the archetype over the intellect as the seat of truth. All this may have favoured the literalist approach based on segmentation, 1-on-1 equivalence, calque translations, use of invariable equivalents, etc., as seen in the late Slavonic version of the Hexaemeron commentaries. As some other Slavonic translations of this period, it seems to be a sort of calque or imprint, indeed a sort of eikôn, of its authoritative Greek archetype. Rather than replace the archetype, the translation makes it expressly present in its own features, and in this way shares in its authority and truth. ${ }^{11}$

\section{Manuscript texts}

Earlier research indeed informs us about the production of this late mediaeval Slavonic counterpart of the Cappadocian commentaries on the Hexaemeron. We also know approximately when and where it was produced - viz. in a monastic context, probably on Athos, in the late $13^{\text {th }}$ or early $14^{\text {th }}$ century - and how it was done - viz. through a literal translation that imitated all formal features of its Greek translation model. This knowledge about the translation as an intellectual product obviously derives from a study of the extant texts, and, more in particular, of the common features that bind all these manuscript texts together in a single tradition, viz. as witnesses to the same act of translation. However, gaining insight into scribes' and readers' reception of this translation implies taking into account also the unique

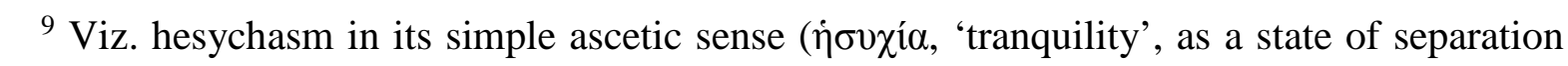
from the distractions of the world, a state of the contemplative soul that has distanced itself from human reasoning, and $v \tilde{\eta} \psi 1 \varsigma$, 'sobriety', as a vigilant and distrustful attitude towards autonomous thoughts and imagination, believed to be traps of the devil) - not hesychasm in its mystical sense, as, for instance, in the claims of Lichačev (who was clearly influenced by 19th-century onomatodoxy, a younger offspring of ancient hesychasm): " [t]he Hesychasts saw in the word the essence of the phenomenon that is referred to by the word, and in the name God God himself." (“Исихасты видели в слове сущность обозначаемого им явления, в имени божьем - самого бога.”) Dmitrij S. Lichačev, 'Nekotorye zadači izučenija vtorogo južnoslavjanskogo vlijanija v Rossii', in Issledovanija po drevnerusskoj literature (Leningrad, 1986), (7-56) 22 (= reprint of its earlier publication in Issledovanija po slavjanskomu literaturovedeniju i fol'kloristike. Doklady Sovetskich učenych na IV Meždunarodnom s"ezde slavistov [Mosvka, 1960], 95-151).

${ }^{10}$ See, for instance, this fragment by the $12^{\text {th }}$-century Byzantine monk, Peter of Damascus: “... for my intellect and my pen are unworthy and impure ... If God puts something into my

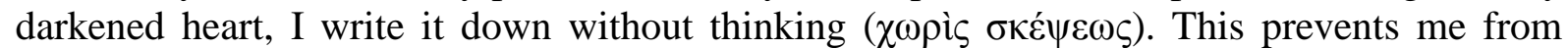
imagining that I am the source of what I have received." - translation from Gerald Eustace Howell Palmer, Philip Sherrard, and Kallistos Ware (eds.), The Philokalia: The Complete Text, Compiled by St Nikodimos of the Holy Mountain and St Makarios of Corinth, vol. 3 (London,

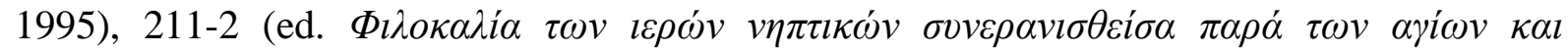

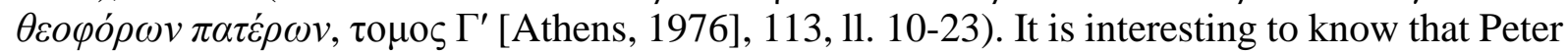
of Damascus' writings were translated into Slavonic; some twenty Slavonic manuscript copies of (parts of) his writings are known to me.

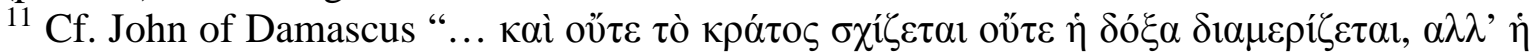

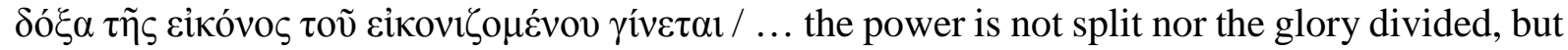
the glory of the image becomes that of the one depicted in the image", see B. Kotter, Contra imaginum calumniatores, 147. 
features of the material texts they produced and read. Between the translator and the reader stands the individual handwritten copy, with its own particulars and agenda. ${ }^{12}$

The extant manuscripts that contain the late Slavonic Šestodnevnik are more than just repositories for the works that interest us here. They are also historical artefacts that provide us with material evidence for the particular acts of text production and consumption in which they were involved. ${ }^{13}$ Scrutiny should not be limited to the Slavonic Hexaemeron corpus alone, but should take into account the overall content and the physical particulars of each of these codices. Five manuscript books are known to contain the Šestodnevnik, all South Slavonic codices of mixed content, written in Serbo-Slavonic orthography and dated to the period between 1400 and the $16^{\text {th }}$ century. ${ }^{14}$

Any codex, with its appearance and specific content (viz. the texts it contains, its marginalia, its decoration and illustrations, ...), ${ }^{15}$ testifies to its own unique history. However, at the time of its genesis this content (in this broad sense of the word) is affected by the model texts used for its production. To trace lines of influence between manuscript books by identifying common traits on various levels - viz. shared formal features, nature and arrangement of content units, specific readings - may allow to catch a glimpse of networks of texts in contact, extant or lost, besides and beyond the textual criticism applied to the copies of the works they may contain.

In the case of the five codices mentioned below, these common traits are by no means limited to the occurrence and particulars of the Šestodnevnik texts. Kinship in language and orthography as well as certain visual similarities (in dimension, decoration, rubrics and layout) may be linked to writing conventions and usage within the compact window in space and time that frames their distribution. At the same time, however, these aspects are affected by the particulars of consecutive model texts. The codices listed here are also bonded by their content beyond the range of the Šestodnevnik, as will become clear below. Although the manuscripts have been described in detail elsewhere, an brief summary is given here: ${ }^{16}$

The Šestodnevnik is the textual heart of the two earliest manuscript books that contain it, both soberly ornamented paper codices of similar, fairly modest dimensions, both containing around 200 folia and measuring c. $30 \times 20 \mathrm{~cm}$., viz. codex Chilandaricus 405 [Ch] (c. 1400) and the first part of the convolute codex Bijelopoliensis 48, from the collection of the Nicholas Church at Nicoljac (near Bijelo Polje, Montenegro) [N], which is slightly younger. ${ }^{17}$ The text of the two Cappadocian Genesis commentaries (ff. 1-180 in Ch, ff. 1-176 in B) takes up some $90 \%$ of these volumes, with the remaining $10 \%$ covering two additional texts, viz. an abridged

${ }^{12}$ On this and the notion of manuscript agency, see Stephen G. Nichols and Siegfried Wenzel (eds.), The Whole Book: Cultural Perspectives on the Medieval Miscellany, Recentiores (Ann Arbor, 1996), 2.

${ }^{13}$ See esp. the introduction to S. G. Nichols and S. Wenzel, The Whole Book (1996).

${ }^{14}$ The limited distribution of the late mediaeval Šestodnevnik stands in stark contrast to that of the earlier Šestodnev, of which over fifty witnesses are known - see Galina S. Barankova and Vladimir V. Mil'kov, Šestodnev Ioanna èkzarcha Bolgarskogo, Pamjatniki drevnerusskoj mysli: issledovanija i teksty 2 (Sankt-Peterburg, 2001), 289-93.

${ }^{15}$ See P. Andrist, P. Canart, and M. Maniaci, La Syntaxe Du Codex (2013), 51: "Nous entendons par contenu d'un codex «le message qu'il transmet à travers un ensemble de signes »".

${ }^{16}$ See L. Sels, De hominis opificio (2009), 21-7, 69-78, with further references.

${ }^{17} \mathrm{Ff}$. 1-193 for the first part (dated by means of the watermarks to c. 1430/40), and ff. 194351 for the second part (dated by means of the watermarks to c. 1350/75), which contains three texts, two vitae and a homily, devoted to John Chrysostom (CPG 7979, 7989, 5819). 
version of the Viae dux-variant of the pseudo-Athanasian Liber de definitionibus (CPG 2254) ${ }^{18}$ and a 'Latin error list', the Pseudo-Photian Opusculum contra Francos. ${ }^{19}$ The combination of the three works, which persists in later codices and testifies to a dogmatic and anti-Latin interest, is clearly early - possibly even original: the stemmatologically related Šestodnevnik versions found in these two codices appear to be closest to the original translation, while these also present the earliest attestations of the two other works, the Liber de definitionibus and the pseudo-Photian Opusculum. This Slavonic cluster of writings may well stem from the Serbian Chilandar Monastery on Athos, ${ }^{20}$ from where it apparently spread to monasteries in presentday Montenegro and the border region of southern Serbia, Macedonia and western Bulgaria.

Indeed, the same texts recur in two later, more richly decorated paper codices that contain

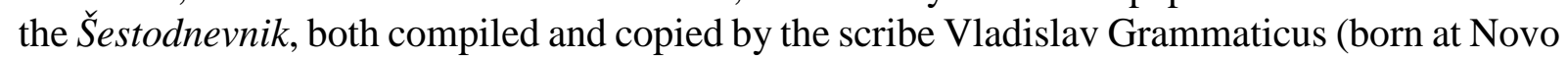
Brdo, fl. 1450s-1480s). ${ }^{21}$ Codex Rilensis 4/14 [R] from the collection of the Monastery of St John of Rila near Sofia, produced in 1456, is a skillfully made book of similar measurements as the earlier codices $(29,5 \times 21 \mathrm{~cm}$.) but containing over 600 folia - the last of which were torn out in the $19^{\text {th }}$ century and are now kept in Odessa. ${ }^{22}$ Its content units can roughly be divided into three parts: comments to the Old Testament, ${ }^{23}$ comments to the New Testament, and a polemical, anti-Latin section. The Šestodnevnik is the first entry in the book (ff. 1-157) and occupies some $25 \%$ of its volume; the Liber de definitionibus marks the transition from the New Testament section to the anti-Latin section, to which the brief Opusculum contra Francos also belongs. Closely related to Vladislav's Rila manuscript is the rather small $(21 \mathrm{x} 14 \mathrm{~cm}$.) but bulky codex now kept in the Academy in Zagreb (HAZU III.a.47) [Z] and known to be copied by Vladislav in 1469. It contains 770 densely written pages, in a minuscule but careful handwriting at an exceptional 42-43 lines per page. The parts that contain the Šestodnevnik and the two related texts seem to have been copied from the same model as codex Rilensis 4/14

18 The Slavonic is an abridged version of the work as it is found in second chapter of Anastasius Sinaita's Viae Dux (CPG 7745, Karl-Heinz Uthemann [ed.], Anastasii Sinaitae Viae Dux, Corpus Christianorum Series Graeca 8 [Turnhout, 1981], 23-75), with several passages omitted, among which the final part (following Uthemann 63, 1. 64).

${ }^{19}$ Ed. Joseph Hergenroether, Monumenta graeca ad Photium ejusque historiam pertinentia (Regensburg, 1869), 62-71. For the contents and Greek precedents of the Opusculum, which is an enumeration of twenty-seven complaints about the Latins, see Lara Sels, 'Lawless, Forbidden and Abominable Customs: O Latiněch sirěč Frugoch, a Slavonic List of Latin Errors', in Michel De Dobbeleer and Stijn Vervaet (eds.), (Mis)Understanding the Balkans. Essays in Honour of Raymond Detrez (Gent, 2013), 271-88.

${ }^{20}$ Its earliest witness is a Chilandar codex, and other manuscripts that contain related texts (viz. the Opusculum and additional texts also found in later Šestodnevnik witnesses) can be linked to the Athonite monastery as well - see cod. 415 in Odessa City Library (Viktor I. Močul'skij, Opisanie Rukopisej V. I. Grigoroviča [Odessa, 1890], 21-25, nr 13/39 = M. M. Kopylenko and M. V. Rapoport, 'Slavjano-russkie rukopisi nerusskogo proischoždenija Odesskoj Gosudarstvennoj Naučnoj Biblioteki imeni A. M. Gor'kogo', Trudy Otdela drevnerusskoj literatury 16 [1960], 550, III/112).

${ }^{21}$ See Gerhard Podskalsky, Theologische Literatur des Mittelalters in Bulgarien und Serbien, 865-1459 (München, 2000), 264-5.

22 Odessa City Library nr 28 - B. Kopylenko and M. Rapoport, 'Rukopisi' (1960), III/111; V. I. Močul'skij, Opisanie (1890), 15/41.

${ }^{23}$ Apart from the Hexaemeron collection the book of Job with catena and comments on the Psalms, Proverbs and Song of Songs. 
(which is probably also be the case for the rest of their overlapping content), ${ }^{24}$ but the Zagrebensis is much richer, comprising six sections, the first hagiographical, the second hexaemeral - viz. the Šestodnevnik on ff. 166-240 (only some 10\% of the volume), to which the Liber de definitionibus is attached -, the third exclusively Chrysostomian, the fourth homiletic, the fifth polemical (anti-Latin) - with the Opusculum contra Francos, among other writings -, and finally the sixth containing original Slavonic, mostly hagiographical works. The circumstances of the production of the codices are known through their colophons, which situates the finishing of the Rila codex in Mlado Nagoričino and the creation of the Zagreb codex in the Matejče Monastery on the Skopska Crna gora (both near Kumanovo in Macedonia). In the Zagreb codex, a letter by Vladislav to Dimitrij Kantakuzin (or Demetrios Kantakouzenos), the man who apparently commissioned the book, reveals that pre-existing text collections were used to compile the massive volume. ${ }^{25}$

Finally, there is codex $42 \mathrm{kept}$ in the National Library of Belgrade [B], a paper codex of modest dimensions $(21 \times 16 \mathrm{~cm}$.) and volume $(197 \mathrm{ff}$.$) . To the first part that contains the$ Hexaemeron (dated c. 1530/37), two more quires have been added (ff. 182-197), probably some 10 à 20 years later, containing texts from the minor prophets in a second hand (perhaps of the same man, at a later date), which has also added marginalia to the first part. ${ }^{26}$ It is the only book that testifies to an isolated existence of the Šestodnevnik, without the two companion texts found in the earlier codices. However, it is uncertain whether the book was considered complete - at least the work of the rubricator remained unfinished (only up to f. 41). Common variant readings as well as formal features of the Šestodnevnik texts (viz. the arrangement of the last text part in the shape of a cross) reveal the (most likely indirect) dependency on Vladislav's copy in the codex Zagrebensis.

\section{Margins}

One aspect of a manuscript book that may float between the particular and the common, between the unique and the traditional, are marginal notes, scholia and glosses. Whereas some marginalia are unique and linked to the history of a specific manuscript, testifying to the way in which a scribe or a reader engaged with (the texts in) that particular book, others go back to underlying transmission layers and point to earlier acts of engagement with the model texts that affected the book's content. In 1900, the learned Michail N. Speranskij believed the many scholia to the Šestodnevnik in Vladislav Grammaticus' impressive codex Zagrebensis to be the

${ }^{24}$ I have abandoned the hypothesis that the Šestodnevnik copy in the Zagrebensis was copied directly from the Rila codex, as argued in Sels, De hominis opificio (2009), 87, and presented in the stemma there, 94.

${ }^{25}$ Vladislav writes: “... After having accepted the commission from Your Excellency that this holy book be composed by us, we have completed [it] with God's assistance, as we already

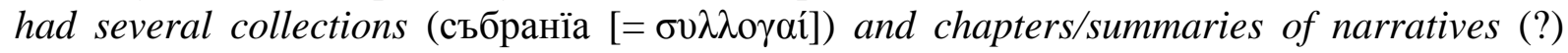

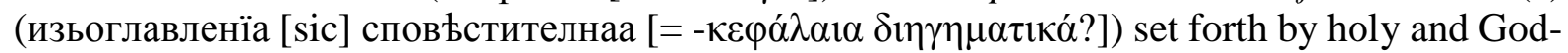
bearing men on the Orthodox Faith and on the future blessed life." - Slavonic text in Borjana Christova, Opis na răkopisite na Vladislav Gramatik (Veliko Tărnovo, 1996), 43. Clearly, among these preexisting collections was the Šestodnevnik and its companion texts, which Vladislav had already used in the Rila codex.

${ }^{26}$ Ljubica Štavljanin-Đorđević, Miroslava Grozdanović-Pajić, and Lucija Cernić, Opis Cirilskih Rukopisa Narodne Biblioteke Srbije, vol. 1 (Beograd, 1986), 80-1. 
work of the scribe from Novo Brdo. ${ }^{27}$ In fact hardly any of these notes are new or unique to the codex or to the scribe.

In the Slavonic Šestodnevnik tradition, unique marginalia bound to a particular codex are found in the $16^{\text {th }}$-century Belgradensis 42 . Many of the marginal notes in this bipartite codex document an act of critical reading, collation and revision of the Slavonic text of the De hominis opificio in the first part of the codex by the scribe of the slightly younger second part. The reviser and scribe of these marginalia thought it useful or even necessary to compare the Slavonic text to a Greek copy, and to improve or clarify the existing Slavonic text on that basis. On f. $114^{\mathrm{r}}$, for instance (the pinax of the De hominis opificio), we find the Greek counterparts of words that may have been considered inaccurate translations (as вь кратць, 'briefly' for $\dot{\varepsilon} \kappa$ $\pi \alpha \rho o ́ \delta o v, ~ ' c u r s o r i l y '$, or вьображенїе, 'formation' for $\sigma \chi \tilde{\eta} \mu \alpha$, 'form, shape'). On f. $134^{\mathrm{v}}$, the complete Greek parallel for that page - which contains a complex passage on the question where the intellect resides in the body (ch. XII, 7-8a) - is written in the left and upper margins. A marginal note points to a large hiatus in chapters 30-31 of the Slavonic De hominis opificio not present in Greek, ${ }^{28}$ and at times the main text is corrected to be in line with the consulted Greek copy, by crossing out the original reading and supplying the new one above the line or in the margins. ${ }^{29}$ Other unique notes contain explanations of passages or terms, for instance, on

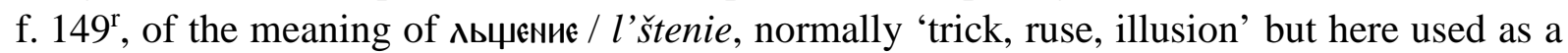
translation for Greek $\tau$ ò $\delta \varepsilon ́ \lambda \varepsilon \alpha \rho$ 'bait' (about a person who is drawn to sin because of his love of money): "the meaning of l'štenie is as when fishermen put flesh or bread or a worm on a hook and they lower it into the deep and the fish comes to swallow what is fastened to the hook, and is immediately caught". ${ }^{30}$ Here the scholium explains not so much the regular meaning of the Slavonic word as the Greek word that underlies the Slavonic. We see a critical and bilingual reader at work, who is carefully checking the Slavonic against a Greek copy, apparently with a concern for textual clarity and correctness. These marginalia are not copied from a model text (as opposed to the few notes in red ink on the first pages of Basil's homilies), but they document a stage of transformation of this particular codex into a new, enriched circulation unit, as the result of a unique act of engagement with the text. ${ }^{31}$

Other marginal notes are not unique to a particular manuscript but are found in both codices copied by Vladislav Grammaticus. Insofar as they appear to have been copied from a common model, they could be said to have a tradition (which probably originated from Vladislav himself, as the model may have been a draft version of his own making). These marginalia present orthographical variants, alternative abbreviations or simple variant readings ${ }^{32}$ - all notes

27 Michail N. Speranskij, 'Zabrebskijat răkopis na Vladislava Gramatika', Sbornik za narodni umotvorenija, nauka i knižnina 16-17 (1900), 325-38.

${ }^{28}$ F. $171^{\mathrm{r}}$, inner margin: 3Ає погр'шшенно ке( ("Here it is mistaken, as in the Greek yet more was written").

${ }^{29}$ On f. $170^{v}$, for instance, the primary reading вь жизмы, 'in life', is crossed out to be replaced bу вь плъти, 'in the flesh', to agree with Greek غ̇v баркí.

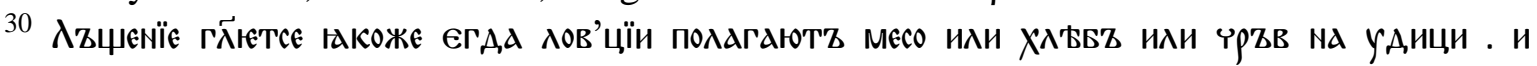

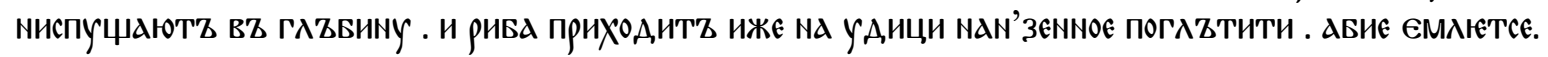

${ }^{31}$ That is, by the addition of a supplementary production unit (the last two quires containing the minor prophets) to the first, and by providing this first unit with new content, namely the corrections and marginalia (= transformations A4 + A2 according to P. Andrist, P. Canart, and M. Maniaci, La Syntaxe Du Codex [2013], 81); Other 'notes de lecture' that point to a comparison with a Greek copy can be found on ff. 3-7 of the Rila codex.

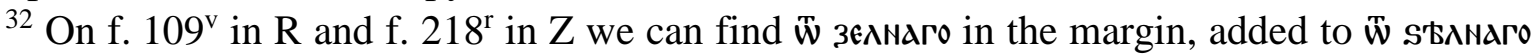
in the main text. The reading in the margin probably presents the reading in Vladislav's model, corrected by him in the main text to what he considered to be the correct orthography. 
associated with the act of copying, and testifying to a concern for orthography and correct writing that is typical of the period. ${ }^{33}$

However, most marginal and interlinear notes are common to all Šestodnevnik copies (although the Belgrade codex has only part of them). ${ }^{34}$ A small number of these copied notes documents the act of translation and can be ascribed to the translator. In these notes we see him

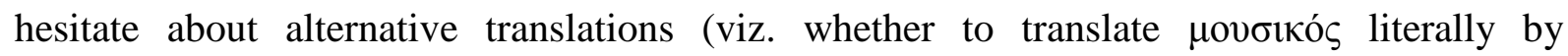

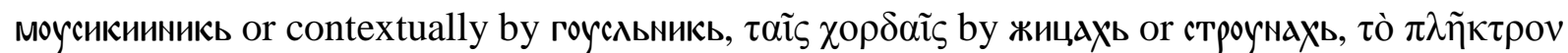
by стр'вкало or врєцАло), ${ }^{35}$ or about the clarity of his typical calque translations (for instance in

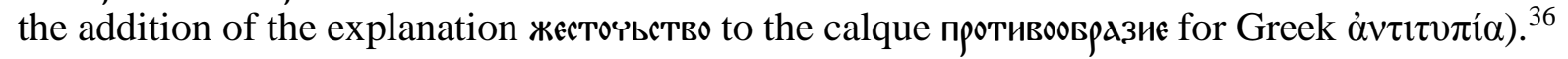

The rest of the shared marginalia was adopted from the Greek and translated together with the main texts. This Greek corpus of notes and scholia of various origin antedates the Slavonic translation by several centuries, as it is found in Greek codices from the tenth and eleventh centuries, such as codex Florentinus Laurentianus gr. IV.27 (A3), Vaticanus gr. 408 (C1) and Oxoniensis Bodleianus Baroccianus gr. 228 (E6). ${ }^{37}$ Many of these notes are merely glossographic: when, for instance, Gregory of Nyssa writes about the respiratory organs, an explanatory gloss is added to $\dot{\alpha} v \alpha \pi v \varepsilon v \sigma \tau 1 \kappa \tilde{\omega} v \sigma \pi \lambda \alpha \gamma \chi v \omega v /$ вьздыхательнымь оутровамь, viz.

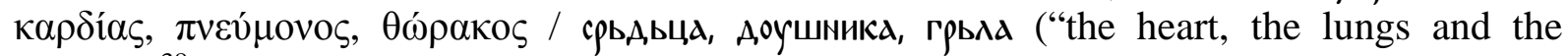
thorax"). ${ }^{38}$ More interesting are those that connect passages from the Cappadocian Genesis commentaries to other philosophical, patristic or medical fragments and opinions. Some scholia belong to the doxographical tradition. In 1910 Giorgio Pasquali published the scholia added to Basil's first homily on the creation. ${ }^{39}$ The great Italian philologist believed this doxographical collection to have taken shape between the $7^{\text {th }}$ and the $9^{\text {th }}$ centuries. ${ }^{40}$ Many of these scholia did not reach the Slavonic translation for reasons we will discuss below, but some did. An example is one of the last scholia in the collection published by Pasquali (XXVIII, p. 201) and the first to appear in the Slavonic version, that is, the one inserted at the point where Basil, in the eleventh

${ }^{33}$ See esp. Harvey Goldblatt, Orthography and Orthodoxy: Constantine Kostenečki's Treatise on the Letters (Skazanie iz'javljenno o pismenech), Studia historica et philologica 16 (Firenze, 1987).

${ }^{34}$ The corpus of copied notes in the Šestodnevnik's De hominis opificio have been published in L. Sels, De hominis opificio (2009), 301-5. In the younger codex Belgradensis the primary marginalia (probably intended to be finished in red ink later) are left out from f. 42 on.

${ }^{35}$ L. Sels, De hominis opificio (2009), 304, M32.

36 Противооврдзиє means 'hardness, resistance' and is not easily understood correctly without the Greek, which is why the translator has added жесточьство, that is, the plain Slavonic word for 'hardness' - see L. Sels, De hominis opificio (2009), 305, M41.

${ }^{37}$ Some other important witnesses to this corpus have not been consulted for this article (because in some aspects, they are further removed from het Slavonic tradition): the $10^{\text {th }}$ century codices Genuensis, Biblioteca Franzoniana, Urbani 17 (E. Amand de Mendieta and S. Rudberg, Tradition manuscrite [1980], 126-9) and Marcianus gr. Z. 58 (119-21), and $11^{\text {th }}$ century codices Vaticanus gr. 405 (91-93) and Athous, Iviron gr. 335 (81-2).

${ }^{38}$ See L. Sels, De hominis opificio (2009), 304, M30.

${ }^{39}$ With as his basis manuscript codex Genuensis, Biblioteca Franzoniana, Urbani 17, but also taking into account A3 (F in Pasquali) and E6 (O in Pasquali), among others. Giorgio Pasquali, 'Doxographica Aus Basiliusscholien', Nachrichten von der könglichen Gesellschaft der Wissenschaften zu Göttingen 1910, 194-228. The scholia to the other homilies were left aside: "[Sie] haben einen grundverschiedenen Character; sie weisen keine so große Gelehrsamkeit auf und sind meistens glossographischen Inhaltes." (194).

${ }^{40}$ G. Pasquali, 'Doxographica' (1910), 215-6. 
section of his first homily, ${ }^{41}$ mentions that some people have introduced a fifth element to the heavens, viz. the ethereal body ( $\alpha i \theta \dot{\varepsilon} \rho 10 v \sigma \tilde{\omega} \mu \alpha$ ), which is neither fire, air, earth, nor water. The Slavonic has the scholium as it is found in A3 and E6 (F and O in Pasquali): " $\pi \varepsilon \dot{\varepsilon} \mu \pi \tau$ v $\sigma \tilde{\omega} \mu \alpha$

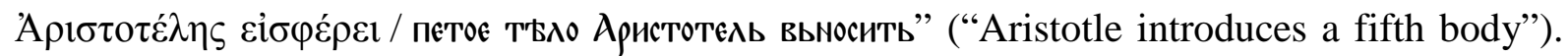
An example that apparently belongs to the same tradition is found in the part of the De hominis opificio, in the twelfth chapter where Gregory discusses the seat of the intellect (

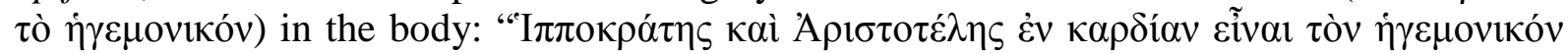

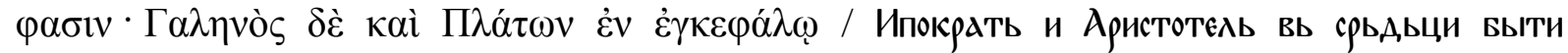
владычьствьноє р'вшє, Галинь же и Платонь вь затилкоу" ("Hippocrates and Aristotle said that the heart is the leading principle, Galen and Plato the brain") ${ }^{42}$

Furthermore, several patristic fragments have been added to Basil's homilies, viz. eight excerpts (six in Slavonic) from Gregory of Nyssa's Apologia in Hexaemeron (CPG 3153), six (five in Slavonic) from Severian of Gabala's In cosmogoniam orationes (CPG 4194; or. i, ii, iv and v) and one from John Chrysostom's Contra Anomoeos homilia 11 (CPG 4324). ${ }^{43}$ As the Slavonic scholia from Gregory and Severian have already been published together with their Greek counterparts and comments, ${ }^{44}$ the sole example here is the still unedited scholium from Chrysostom. ${ }^{45}$ When in the sixth section of the ninth homily Basil touches upon the plural in the divine saying "Let us make man in our image", refuting the Jewish (Philonic) interpretation that God is here talking to the angels and defending an implied reference to the Son, ${ }^{46}$ the added scholium presents the reader with a similar argument from the eleventh homily Against the Anomoeans by John Chrysostom. ${ }^{47}$

Finally, there is an interesting, long medical scholium added to the last chapter of Gregory of Nyssa's De opificio hominis, which deals with a fiery aspect proper to the human heart

${ }^{41}$ Bas. Hex. I.11 (E. Amand de Mendieta and S. Rudberg, Homilien zum Hexaemeron [1997], 18, 11. 17-8).

${ }^{42}$ L. Sels, De hominis opificio (2009), 304, M28.

${ }^{43}$ Also mentioned in G. Pasquali 'Doxographica' (1910), 194, note 3.

${ }^{44}$ See for the scholia from Gregory of Nyssa Lara Sels, 'Scholia from Gregory of Nyssa's Apologia in Hexaemeron in the Fourteenth-Century Slavonic Hexaemeron Collection', Scripta \& e-Scripta 14-15 (2015), 95-119, and for those from Severian of Gabala Lara Sels and Sarah Van Pee, 'Scholia from Severian of Gabala's In Cosmogoniam Homiliae in the 14th-century Slavonic Hexaemeron Collection', in Adelina Anguševa et al., Vis et Sapientia: Studia in Honorem Anisavae Miltenova. Novi izvori, interpretacii i podchodi v medievistikata (Sofija, 2016), 89-110.

${ }^{45}$ Which is left without a reference in the 1997 Hexaemeron edition by Amand de Mendieta and Rudberg, even though it is found in A3 (f. 185 ${ }^{\mathrm{v}}$ ), C1 (f. $88^{\mathrm{r}}$ ) and E6 (f. $64^{\mathrm{r}}$ ).

${ }^{46}$ E. Amand de Mendieta and S. Rudberg, Homilien zum Hexaemeron (1997), 158, $\S 2-159, \S 1$.

$47 P G$ 48, 798 11. 41-48; 800, 1.1-11 (but slightly different as a scholium: "Mé $\lambda \lambda \omega v$

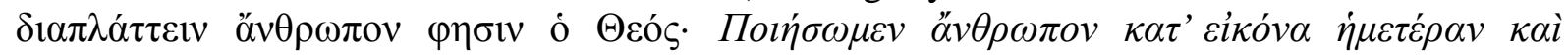

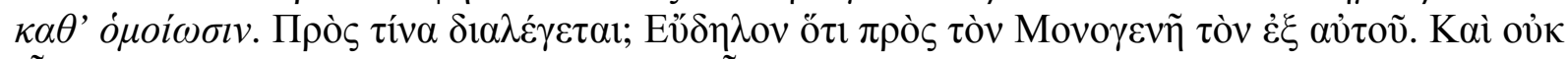

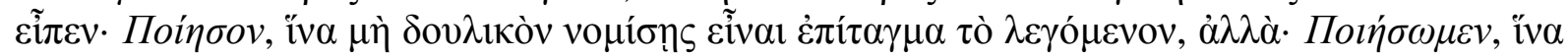

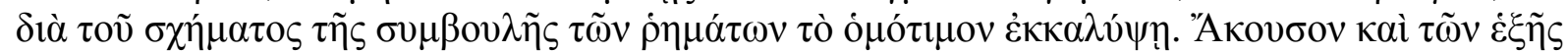

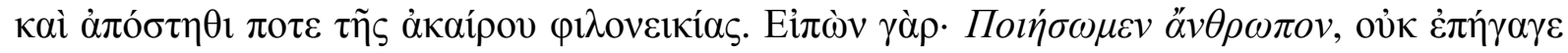

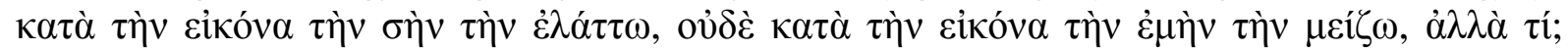

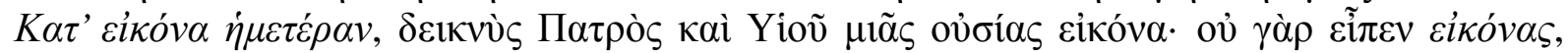

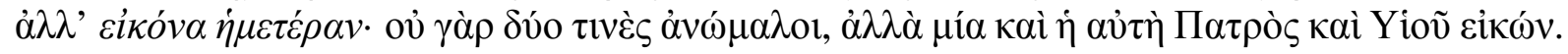

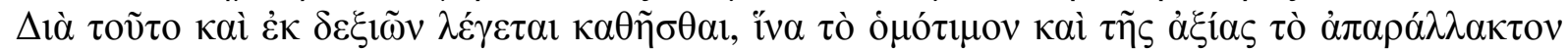

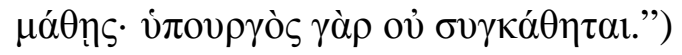




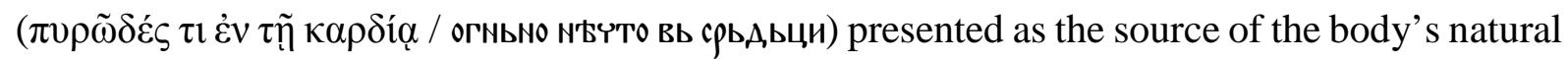

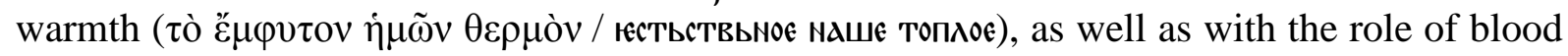

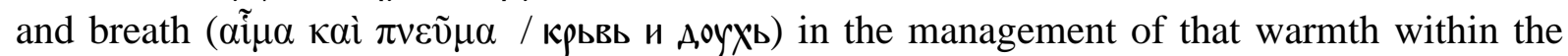
body parts. $^{48}$

All these marginalia of Greek origin stem from earlier acts of engagement with the texts, from attentive and critical reading and comparison with other writings and points of view. Through their translation together with the main texts of the Šestodnevnik, they entered the Slavonic tradition and became part of reading environments other than the ones that originally gave rise to them. The familiarity with ancient philosophy, the medical and astronomical knowledge and, more generally speaking, the inquisitive interest in the confrontation of various writings and opinions belongs to the Greek rather than to the Slavonic tradition. The reason that these scholia were translated into Slavonic was faithfulness to the Greek exemplar. Most Šestodnevnik scholia that belong to the Slavonic tradition proper - related to the acts of translating, copying and collating - are concerned with correctness and source text authority. This fits the late medieval monastic environment that initially gave rise to the literal Šestodnevnik translation and that later produced and fostered the manuscript books that bear witness to it.

The accumulated layers of Greek commentators', Slavonic translator's, copyists' and readers' notes should not be considered a negligible corpus alienum. They document the lives of the Cappadocian hexaemeral works as they have materialized in a network of individual manuscript texts, extant or now lost, in particular historical circumstances.

\section{As an Appendix: On Artifacts and Origins}

The traditional scholia, viz. the ones that were adopted from the Greek, proved helpful to trace the origins of the Šestodnevnik and to partly reconstruct the undocumented moment of translation, when a particular Greek model text gave rise to the Slavonic version. Looking at the Slavonic occurrences of the patristic scholia, the absence of the fragments normally added to the first chapter of Basil's Homiliae is striking, ${ }^{49}$ especially as in the rest of the Šestodnevnik the Slavonic corpus of scholia is more complete than that in any of the studied Greek texts. At first glance, none of the Greek copies qualifies as a model for the Slavonic translation, as none has all scholia to homilies 2-9 and none seems to provide an explanation for the absence of the scholia normally added to the first homily.

\begin{tabular}{|ll|c|c|c|c|}
\hline \multicolumn{1}{|c|}{ Scholia } & $\begin{array}{c}\mathrm{A} 3 \\
\text { Laur. gr. IV.27 }\end{array}$ & $\begin{array}{c}\mathrm{C} 1 \\
\text { Vat. gr. 408 }\end{array}$ & $\begin{array}{c}\text { E6 } \\
\text { Baroc. gr. 228 } \\
(=\mathrm{F5} \text {, E26) }\end{array}$ & Slav. \\
\hline I. & $\mathrm{S}^{\text {SevGab }}$ 1, to Hex. I.1 & $\mathrm{X}$ & - & - & - \\
\hline II. & $\mathrm{S}^{\text {SevGab }}$ 2, to Hex. I.5 & $\mathrm{X}$ & - & - & - \\
\hline III. & $\mathrm{S}^{\text {Nyss }}$ 1, to Hex. I.6 & $\mathrm{X}$ & - & $\mathrm{X}$ & - \\
\hline IV. & $\mathrm{S}^{\text {Nyss }}$ 2, to Hex. I.7 & $\mathrm{X}$ & - & $\mathrm{X}$ & - \\
\hline V. & $\mathrm{S}^{\text {Nyss }}$ 3, to Hex. II.1 & $\mathrm{X}$ & - & - & $\mathrm{X}$ \\
\hline VI. & $\mathrm{S}^{\text {Nyss }}$ 4, to Hex. II.7 & $\mathrm{X}$ & $\mathrm{X}$ & $\mathrm{X}$ & $\mathrm{X}$ \\
\hline VII. & $\mathrm{S}^{\text {SevGab }}$ 3, to Hex. II.7 & $\mathrm{X}$ & - & $\mathrm{X}$ & $\mathrm{X}$ \\
\hline VIII. & $\mathrm{S}^{\text {SevGab }}$ 4, to Hex. II.7-8 & $\mathrm{X}$ & $\mathrm{X}$ & $\mathrm{X}$ & $\mathrm{X}$ \\
\hline
\end{tabular}

${ }^{48}$ Ed. L. Sels, De hominis opificio (2009), 284-6.

${ }^{49}$ The Slavonic tradition has one scholium from Severian of Gabala in the first homily that has nothing to do with the corpus as we also know it in the Greek tradition - see L. Sels and S. Van Pee, 'Scholia from Severian of Gabala' (2016), 91-2. 


\begin{tabular}{|ll|c|c|c|c|}
\hline IX. & S $^{\text {Nyss }}$ 5, to Hex. II.8 & $\mathrm{X}$ & $\mathrm{X}$ & $\mathrm{X}$ & $\mathrm{X}$ \\
\hline $\mathrm{X}$. & $\mathrm{S}^{\text {Nyss }}$ 6, to Hex. III.2 & $\mathrm{X}$ & $\mathrm{X}$ & $\mathrm{X}$ & $\mathrm{X}$ \\
\hline XI. & $\mathrm{S}^{\text {Nyss }}$, to Hex. III.3 & - & - & $\mathrm{X}$ & $\mathrm{X}$ \\
\hline XII. & S $^{\text {yss }}$ 8, to Hex. III.4 & $\mathrm{X}$ & - & - & $\mathrm{X}$ \\
\hline XIII. & S S$^{\text {SevGab }}$ 5, to Hex. VII.1 & $\mathrm{X}$ & $\mathrm{X}$ & $\mathrm{X}$ & $\mathrm{X}$ \\
\hline XIV. & S $^{\text {Chrys }}$ 1, to Hex. IX.6 & $\mathrm{X}$ & $\mathrm{X}$ & $\mathrm{X}$ & $\mathrm{X}$ \\
\hline XV. & S $^{\text {SevGab }}$ 6, to Hex. IX.6 & $\mathrm{X}$ & $\mathrm{X}$ & $\mathrm{X}$ & $\mathrm{X}$ \\
\hline
\end{tabular}

This observation is especially disappointing with regard to the $10^{\text {th }} / 11^{\text {th }}$-century Oxford codex, Baroccianus gr. 228 (E6), ${ }^{50}$ which has many important features in common with the Slavonic version. ${ }^{51}$ Generally speaking it does share the same corpus of doxo- and glossographic, patristic and medical scholia, though the occurrences of individual scholia do not seem to match. However, a closer look at E6 offers a more nuanced picture. ${ }^{52}$

The Baroccianus / E6 contains the Hexaemeron corpus on ff. $1-118^{\mathrm{v}}$ and Basil's homilies on ff. 1-64, with the order of the folia muddled (instead of correct 1, 3-8, 2, 9-65 ${ }^{53}$ ). ${ }^{54}$ For most part, what we see is a carefully written $10^{\text {th }} / 11^{\text {th }}$-century parchment codex, its margins filled with glosses and scholia. However, ff. $1-3^{55}$ as well as $17-24^{56}$ offer a completely different view: these eleven paper leaves have been supplied around the fourteenth century to replace the probably damaged original parchment folia I, II and VIII (later misbound out of order), and XVIIXXV. The replacement leaves contain a new copy of the main text, but their margins are left blank, without scholia. Folia 1, 3 and 2 contain parts of the first two homilies of Basil's

${ }^{50}$ See for a description E. Amand de Mendieta and S. Rudberg, Tradition manuscrite (1980), 138-42; O. Coxe, Catalogi Codicum Manuscriptorum Bibliothecae Bodleianae Pars Prima Recensionem Codicum Graecorum Continens, Quarto Catalogues I (Oxford, 1883), 393-4 (repr. with corrections 1969).

${ }^{51}$ Baroccianus 228 / E6 contains the 'regular Hexaemeron corpus' as it is reflected in the Slavonic, with which it is clearly textually related, as seen in the many shared variant readings. More specifically, E6 has the same rare title for Gregory of Nyssa's De hominis opificio, viz.

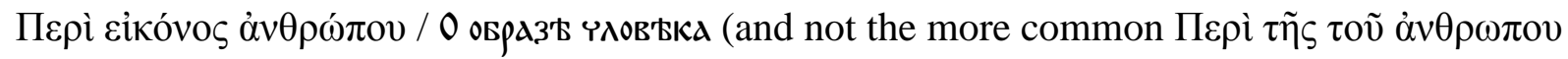
$\kappa \alpha \tau \alpha \sigma \kappa \varepsilon v \tilde{\eta} \varsigma$, with variants), and it has the same division of Gregory of Nyssa's treatise in 31 (not 30) chapters (as chapter 12 is split up), which is also reflected in the pinax.

52 A complete reproduction of E6 is available online, as most of the Bodleian's Greek Barocci collection has been scanned for the Polonsky Foundation Digitization Project (link https://digital.bodleian.ox.ac.uk/inquire/p/2dd604eb-3a11-4d41-8319-e65af34d71ef). I should like to express my gratitude to Dr Bruce Barker-Benfield, who was so kind to provide me with additional codicological information, esp. on the codex's quire structure and consecutive repairs (email of 16 April 2018).

${ }^{53}$ Fol. 2 was apparently misplaced before the time of the Bodleian's ink foliation, probably at the time when the present binding in brown leather was put in place for the Bodleian Library after the manuscript's arrival at Oxford in 1629 (late 17th or early 18th century) - mail Bruce Barker-Benfield, 'Baroccianus 228' (16 April 2018).

${ }^{54}$ The rest of the codex (ff. 119-206) contains some genuine and spurious correspondence to and from Basil (see Paul Jonathan Fedwick, Bibliotheca Basiliana Universalis: A Study of the Manuscript Tradition of the Works of Basil of Caesarea. 1: The Letters, vol. 1, Corpus Christianorum, Bibliotheca Basiliana Universalis [Turnhout, 1993], 144, Ev4), besides Contra Eunomium (GPG 2837) and De spiritu (CPG 2838).

${ }^{55}$ With f. 2 replacing the missing eighth parchment leaf of the first quire (cut out between the present ff. 8 and 9.

${ }^{56}$ They replace the original third quire and the missing first leaf of the fourth (before f. 25). 


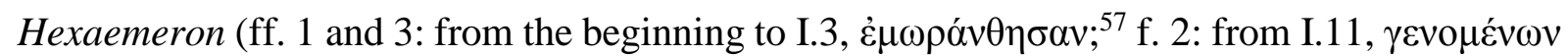

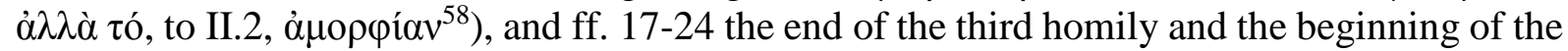

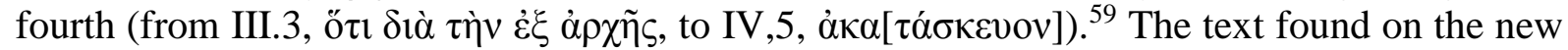
leaves is not in line with the Slavonic translation, contrary to that in the original part of the codex.

The Baroccianus must have been considered an excellent model text, as its Hexaemeron was copied at least twice in the $15^{\text {th }}$ century, after its repair: the versions found in codex Vindobonensis theologicus gr. 113 (or F5) ${ }^{60}$ and codex Oxoniensis Bodleianus Baroccianus gr. 85 (E26) ${ }^{61}$ mirror the mixed state of the text as it is still found in the mended codex today. The bare fact of the $14^{\text {th }}$-century repair tells us that, already at that time, E6 showed signs of wear: its first and third quire must have been defect, with some folia damaged. A study of the parallels and differences between the Slavonic Šestodnevnik and E6 - a.o. on the basis of the presence of the scholia - reveals that also the Sestodnevnik may have derived from the Hexaemeron corpus in E6, although this must have happened indirectly, through an intermediary Greek copy of $\mathrm{E} 6^{62}$ that must have been made before the $14^{\text {th }}$-century repair, and with recourse to another copy of Basil's Hexaemeron for the first part of its text. ${ }^{63}$ On the one hand, the Slavonic translation shows a more complete version than the one we find in E6 today, while, on the other, it also testifies to the fact that the old codex's first quire was already damaged and its leaves loose at the time when the intermediary copy was made: the text versions start to match almost perfectly at f. 8 in E6 (i.e. f. VII in the old quire structure; from homily I.11 on), which indicates that the codex offered the copyist a secure text from that point on. ${ }^{64}$ The text parts now supplied by f. 2 and the paper leaves replacing the third quire were still in their original state when E6 served as a model for the Greek exemplar of the Slavonic Šestodnevnik - the latter indeed

${ }^{57}$ E. Amand de Mendieta and S. Rudberg, Homilien zum Hexaemeron (1997), 7, 1.8 (homily I is found on ff. [1] $+[3]+4-8+\left[2^{r}\right]$, in that order).

${ }^{58}$ E. Amand de Mendieta and S. Rudberg, Homilien zum Hexaemeron (1997), 20, 1. 8 - 23, 1. 15 (homily II is found on ff. [2] + 9-15, in that order).

${ }^{59}$ E. Amand de Mendieta and S. Rudberg, Homilien zum Hexaemeron (1997), 42, 1.18 - 64, 1. 4 (note that homilies III-IV are on ff. $15-16+[17-24]+25-27$ ).

${ }^{60}$ E. Amand de Mendieta and S. Rudberg, Tradition manuscrite (1980), 180-81. (and for the letters, see Fedwick, Basil of Caesarea, The Letters, 1:145, Ev5)

${ }^{61}$ E. Amand de Mendieta and S. Rudberg, Tradition manuscrite (1980), 167-8.

${ }^{62}$ In a few places, both in the Homiliae in Hexaemeron and in the De hominis opificio, the Slavonic is based on secondary readings that can be shown to derive from more ancient ones in E6. A nice example is found in the $21^{\text {st }}$ chapter of the De hominis opificio (G. H. Forbes, 'De Conditione Hominis' [1855], 226, L. Sels, De hominis opificio [2009], 218-9): there, the

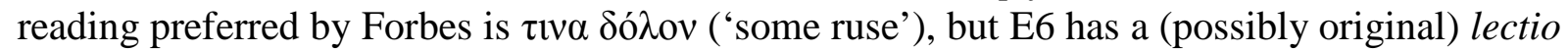

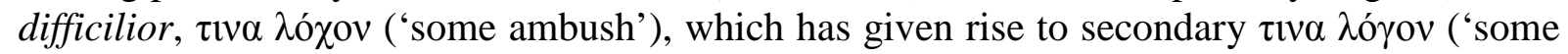
word'), which matches the Slavonic translation слово.

${ }^{63}$ The first part of the Slavonic translation reflects another version of the Greek text, which is difficult to identify on the basis of the 1997 edition by Amand de Mendieta and Rudberg, which is based on a collation of no more than eleven witnesses.

${ }^{64}$ So from the original seventh folio on, which indicates that the inner part of the quire $-\mathrm{ff}$. III-IV/V-VI (viz. two bifolia, today's ff. 4-5/6-7) - was severed from the rest (normally ff. I-II/VIIVIII, corresponding to today's paper ff. $1+3$ and parchment f. $8+$ paper f. 2 ), of which ff. I-II were apparently already damaged or removed. At the time of the later repair the original ff. IIIVI (now ff. 4-7) were rebound together with the new paper leaves. 
preserves scholia 5 (to homily II.1) and 12 (to homily III.4). There are no indications that any other part of the text was already defect or lost at that time. ${ }^{65}$

All of this allows us to conclude that the extremely literal Slavonic Šestodnevnik translation, probably made on Mount Athos in the late $13^{\text {th }}$ or early $14^{\text {th }}$ century, can be identified as a descendant, through an intermediary Greek copy, of an earlier circulation unit of E6 (that is, the codex in a material state preceding its $14^{\text {th }}$-century repair). For the first part of Basil's Hexaemeron (up to I.10) another, still unidentified version was used, which explains the absence of the scholia to the first homily.

As a physical object a codex has its own unique history, which may be intimately bound up with the history of other manuscript texts: if it served as an exemplar, its material particularities affected the content of its copy and the further tradition - also in translation - of the works it contains. The (descendants of the) copy, on the other hand, may provide documentation for a stage in the material life of the model that would otherwise remain unknown. In spite of the rigorous distinction that, from a methodological point of view, is drawn between 'work' and 'text', and in spite of the occasional dissent between scholars more inclined towards the study of works and origins on the one hand and of manuscripts as artifacts on the other, the two aspects of textual scholarship cannot be severed in actual practice. This is overtly clear from the example of the Šestodnevnik marginalia and from the ensuing observations concerning its origins and translation model.

\section{SUMMARY}

The Cappadocian Fathers' hexaemeron Commentaries, viz. Basil of Caesarea's Homiliae in Hexaemeron (CPG 2835 ) and Gregory of Nyssa's De hominis opificio (CPG 3154) were translated into Slavonic (for the second time) in the late $13^{\text {th }}$ or early $14^{\text {th }}$ century. This paper explores the strata of the many and multifarious marginal and interlinear notes, scholia and glosses, found in the five codices - all South Slavonic mixed content manuscripts dated to the period between 1400 and the $16^{\text {th }}$ century - that bear witness to this extremely literal late medieval Slavonic Šestodnevnik. It is argued that the accumulated corpus of Greek commentators', Slavonic translator's, copyists' and readers' notes documents the lives of the Cappadocian works as they have materialized throughout the ages in a network of individual manuscript texts. Most Šestodnevnik marginalia that belong to the Slavonic tradition proper are related to acts of translating, copying and collating, and are shown to testify to a concern for correctness and source text authority, while most of the inherited marginalia of Greek origin are either glossographic or belonging to the doxographical tradition, showing an interest in related writings and opinions.

In an appendix, starting from observations on the occurrence of scholia inherited from the Greek tradition, the Slavonic Šestodnevnik is shown to derive, through an intermediary copy, from an earlier circulation unit of the $10^{\text {th }} / 11^{\text {th }}$-century Greek codex Oxoniensis Baroccianus graecus 228 (E6), that is, from the codex in a state preceding its $14^{\text {th }}$-century repair. While the identification of the Baroccianus as the ultimate model of the Šestodnevnik greatly enhances the assessment of the Slavonic version, the latter documents a stage in the material life of the Baroccianus that would otherwise have remained unknown.

65 There is also no sign in the Slavonic translation of a lacuna in the text part of the fourth quire, where in today's E6 another parchment leaf is missing, viz. between ff. 29 and 30, for which there is no paper replacement. 